\title{
Endemic birds of the Fynbos biome: a conservation assessment and impacts of climate change
}

\author{
ALAN T. K. LEE and PHOEBE BARNARD
}

\begin{abstract}
Summary
The South African Fynbos biome, a global biodiversity hotspot with high endemism and species richness, has six endemic bird species. These are important not only intrinsically, but also for ecological functioning and as flagships for South Africa's economically valuable avitourism sector. Little is known about population sizes or realised distribution ranges of these six species, but projected range modelling based on occurrence from the South African Bird Atlas Project (SABAP) has suggested these species are vulnerable to climate change. We estimate global population sizes for these six endemics based on densities calculated from two intensive biome-wide point count surveys in 2012. We modelled regions of suitable climatic space, from which we established that mean annual temperature and the temperature of the warmest quarter of the year appear to limit Cape Rock-jumper Chaetops frenatus and Protea Canary Serinus leucopterus ranges. Both species have seen an apparent $>30 \%$ decrease in range and reporting rates (a proxy for abundance) in the twenty years between SABAP atlas periods (1987-1991 and 2007-ongoing). The Cape Rock-jumper result is unexpected: encounter rates are higher in shorter vegetation, dry slopes and habitats with more recent occurrence of fire - all proxies for proximate causes of climate change on the Fynbos. Although coastal plains are highly transformed, mountain Fynbos is the best protected of all the world's Mediterranean-climate habitats, with relatively little anthropogenic land transformation. Long term weather datasets from the Fynbos demonstrate significant warming since 1960. We conclude from these lines of evidence that these decreases are consistent with the loss of suitable climate space and inability of these species to adjust physiologically to increasing temperatures.
\end{abstract}

\section{Introduction}

The Fynbos region at the south-western tip of Africa is one of five Mediterranean-type biomes of the world. All five are considered global conservation priority areas owing to high plant species diversity and density, as they cover just $2 \%$ of the Earth but account for $20 \%$ of the Earth's vascular plant species (Cowling et al. 1996, Myers et al. 2000, Olson and Dinerstein 2002). By 2100, the Mediterranean biomes are projected to experience the largest proportional loss of biodiversity of all terrestrial biomes due to their significant sensitivity to multiple biodiversity threats and interactions among these threats (Sala et al. 2000). For example, the biomes' mild climate and proximity to the ocean makes them attractive to humans, resulting in disproportionately high conversion for agriculture, development, and other human uses. In addition, extensive global climate change modelling on the impacts on avian biodiversity suggests that the south-western corner of South Africa is an area at risk (Foden et al. 2013). Furthermore, modelling exercises of all the five Mediterranean-climate habitats suggests the Fynbos is one of the two facing greatest potential changes in climate (Klausmeyer and Shaw 2009). 
Species that are both highly climate change vulnerable and threatened, as well as the regions in which they are concentrated, deserve particular conservation attention to mitigate current threats and to plan for future climate change adaptation interventions. Africa (excluding the Sahara and Congo basin) has been identified as one of these regions (Foden et al. 2013). Several African bird species have been identified as being potentially vulnerable to climate change due to restriction to upper-montane areas or other life-history traits (Monadjem et al. 2013, Simmons et al. 2004). To date there have been few studies that have validated these predictions from Africa.

Climate in the Fynbos is predicted to get drier and hotter (Klausmeyer and Shaw 2009) and is already experiencing an increase in extreme weather events (Kruger and Sekele 2013). While fires are an important natural disturbance essential to the life-history strategies of many Fynbos plant species, there are also indications from several sources that climate changes are resulting in detrimental increases in fire frequency (Kraaij et al. 2012, Southey 2009, Wilson et al. 2010). Previous studies of the probable impacts of climatic change on plants of the Fynbos biome have highlighted a likely reduction in biome extent, species' range displacements and potential extinctions (Midgley et al. 2002). Huntley and Barnard (2012) projected similar outcomes for birds associated with the Fynbos and grassland biomes in southern Africa. Du Plessis et al. (2012) and Cunningham et al. (2013) have also shown that in arid environments of South Africa, increasing temperatures have repercussions for behaviour, foraging success, body mass maintenance, and ultimately reproductive output for at least two bird species.

The Fynbos is an important habitat type in terms of avian species richness for South Africa. It supports six endemic passerine bird species (Barnes 1998, BirdLife International 2013) and a further six of South Africa's 18 endemics are frequently encountered here (Lee unpubl. data). The avian community of mature mountain Fynbos is dominated by the endemic nectarivores Cape Sugarbird Promerops cafer and Orange-breasted Sunbird Nectarinia violacea (Siegfried and Crowe 1983). Insectivorous Victorin's Scrub-warbler Bradypterus victorini is associated with rank vegetation of mesic mountain Fynbos (Fraser 1997a), while Cape Rock-jumper Chaetops frenatus prefers open, rocky habitats associated with ridges or mountain tops (Maclean 1993). Granivorous Cape Siskin Crithagra totta occurs in habitats dominated by Restios (Fraser 1997b), while Protea Canary Serinus leucopterus is associated with open, often arid, Fynbos with a dispersed canopy of tall Protea (Milewski 1976).

We aim to provide information that will inform decision-making processes regarding the conservation status of these species, with special reference to the vulnerability of some of them to climate change. To do so we calculate population sizes, global ranges, and examine population trends from bird atlas data. Climate change may influence species' distributions directly, through species' intolerance for temperature extremes, or indirectly through modifications of habitat (specifically vegetation) by temperature, rainfall and vulnerability to fire. We predict species will differ in their responses to climate-related influences on vegetation, but that all will display thermal intolerance for warm temperatures as this is a trend observed for high-elevation bird species (Sekercioglu et al. 2008), and Fynbos biota evolved under mainly cooler conditions (Midgley et al. 2005).

\section{Methods}

\section{Study area}

Fynbos is a biome restricted within the political boundaries of South Africa, mostly its Western and Eastern Cape provinces (Figure I). While geophytic plant families (e.g. Iridaceae) dominate recently burnt Fynbos landscapes, more mature Fynbos is dominated by Proteaceae, Ericaceae and Restionaceae (Cowling 1995). We used the range map for Fynbos from Mucina and Rutherford (2006) to determine the scope of our geographical survey. We excluded the Karoo Renosterveld bioregion (included with Fynbos by some authors) as there are no historical records of the presence of any of the Fynbos endemic bird species in that region. In addition, we excluded the East 


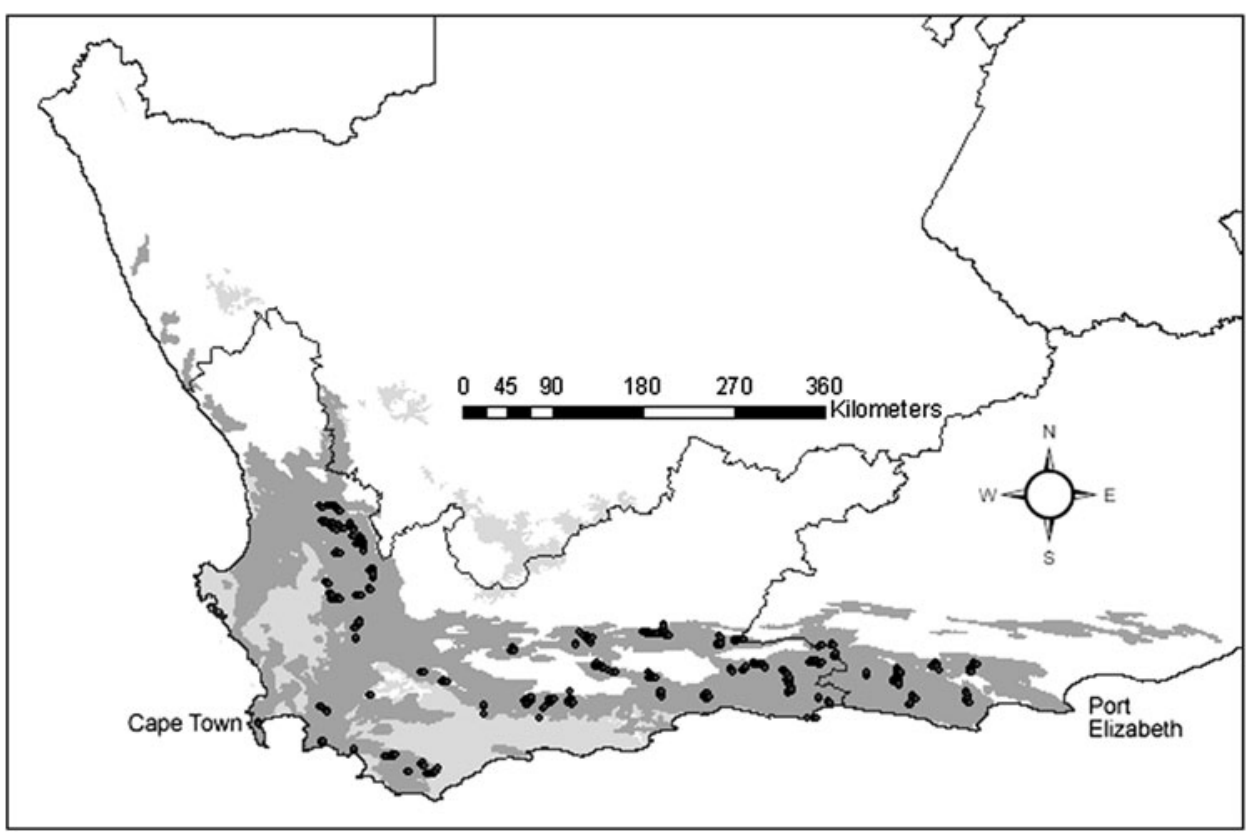

Figure 1. A map of the study area, south-western South Africa. The Fynbos bioregions considered suitable for the presence of the Fynbos endemic birds are shaded dark grey, while the additional bioregions that make up the official extent of the Fynbos biome per Mucina and Rutherford (2006) are shaded in light grey. The location of survey points are indicated as dots. The thin grey lines represent provincial boundaries of South Africa.

and West Coast Renosterveld, as these have been dramatically transformed by agriculture (Kemper et al. 1999). The remaining bioregions cover an area of 58,126 km² (Figure 1), which for all these species is a maximum 'extent of occurrence' (the area contained within the shortest continuous imaginary boundary which can be drawn to encompass all the known, inferred or projected sites of present occurrence of a species, excluding cases of vagrancy: IUCN Red List criteria definition).

\section{Density estimates}

A point count survey using distance sampling techniques (Buckland et al. 2005) was conducted by ATKL across the biome in the austral summer from January to May 2012 (899 points) with some repetition of survey effort in the austral spring from August to October (65\% coverage, complete resampling was not possible due to extreme weather conditions during this period). Counts were conducted from daybreak (o5hoo summer, ophoo winter) for up to four hours, and from 15 hoo until dusk along survey lines between five and $10 \mathrm{~km}$ long (depending on terrain). Points were located between 0.5 and $\mathrm{I} \mathrm{km}$ apart to help ensure detection independence. The survey design was semi-stratified with survey lines separated in order to cover as much of the biome as possible. Survey lines were generally oriented to cover the range of altitudinal gradients and aspect at each site and we often made opportunistic use of existing tracks. This semi-stratified sampling design has implications for the validity and variation of the presented density estimates where the confidence intervals may be wider than those reported (Fewster et al. 2009). A true random survey was impossible to implement owing to the complicated nature of land ownership combined with inhospitable mountain terrain and budget constraints. GPS locations were taken for all points, 
together with altitude. Vegetation height was calculated as the average height of dominant plant species or functional groups within $25 \mathrm{~m}^{2}$ radius of the observer, with height recorded as $<0.25 \mathrm{~m}$, $0.5 \mathrm{~m}$, and in $0.5 \mathrm{~m}$ increments from thereon, weighted by cover of each species or functional group (a Braun-Blanquet method modified from Siegfried and Crowe 1983). Measurements were taken to the centre of groups of birds using a Bushnell ScoutPro ${ }^{(\mathrm{tm})}$ rangefinder. Birds recorded as flying or that perched after initiation of the point count were not included in final analysis to conform to the snapshot paradigm of the distance sampling technique, although these data were taken for association with habitat and group size calculations.

All analyses were undertaken in Distance 6.o (Thomas et al. 2010), using the multi-covariate distance sampling engine with altitude and vegetation height as covariates, and results stratified by time-since-fire categories. Time since fire was estimated in the field from growth nodes of Protea or Leucospermum species where possible, and cross-checked against local knowledge or fire incidence maps held by CapeNature, a provincial conservation body. We present stratified results by fire category as we have two non-numerical categories which make this data layer unsuitable for use as a continuous covariate. These two categories are a 'mixed' category (where it was clearly evident for a point that the surrounding landscape had experienced different fire histories at a level > 5 years) and a 'not-applicable' category for ecotone habitats where fire is no longer a useful factor for describing vegetation structure. This includes ecotonal transitions from Fynbos to Karoo and Fynbos to Forest. For these scenarios, it is likely that time since fire was $>20$ years, but the vegetation clearly differs from Fynbos in terms of dominant plant species and senescence. Furthermore, the results show that consideration of the disturbance state of the surveyed area has implications for detection of a species, which in turn has implications for modelling bioclimatic space (see below). Encounters from the two survey periods were combined, as suggested by Buckland et al. (2008) for all species except Cape Siskin, where there was a significant difference in group encounter rates between surveys in initial exploratory pair-wise analysis by point. Overall densities for Cape Siskin were thus calculated based on the more comprehensive summer survey period only. Points where fire had occurred between surveys were omitted. Population estimates were calculated by multiplying the area of the extent of occurrence $\left(58,126 \mathrm{~km}^{2}\right)$ by lower and upper $95 \%$ confidence-interval global density estimates for each species.

\section{Species vulnerability to climate change influences on vegetation structure}

A climate that is drier, warmer and more prone to fire will result in a decrease in height of the overall vegetation structure in the Fynbos where tall, slower growing Proteaceae species are replaced by fire ephemerals and grasses (e.g. Chalmandrier et al. 2013). We correlate bird species' group encounters at the point count level with average vegetation height to identify species preferences for vegetation height categories. We used non-parametric tests to explore relationships between variables influencing vegetation height: we compared vegetation height for points using Kruskal-Wallis tests, and examined correlations between vegetation height and altitude with Spearman's rank coefficients.

\section{Suitable climate-space and range modelling}

Absence of bird species within the point count dataset are to a degree a function of the state of the natural fire disturbance cycle of the Fynbos (see Results). Together with the relatively small sampling window at each point, this means we cannot presume observed absences of species are true absences in terms of climatic suitability. Therefore, we used MaxEnt (Phillips et al. 2004) to model suitable climatic space based on 19 variables of the Worldclim bioclimatic dataset at a fine $I^{\prime}$ resolution (Hijmans et al. 2005b). We used species presence data from the survey as well as other incidental encounters with target species outside the survey from 2012.

For modelling, the area within the South Africa political boundary was used as the background selection, as we are confident of the absence of species from areas outside the Fynbos. The models 
were run using logistic output format; with 15 replicates and the 'subsample' replicate run type, with the number of iterations for model convergence set to 5,000; the random test percentage of survey points was set to 25 ; and the jackknife routine was used to measure variable importance. We correlate variable importance (training gain for each variable) against mean evaporative water loss inflection points from Milne (2014), which indicate a species vulnerability to warm temperatures (these are points where a species' evaporative water loss starts to increase at higher temperatures). The 1o percentile training presence logistic threshold was used to define the minimum probability of suitable climatic space (Young et al. 2011). We summed the area of suitable space polygons as a measure of minimum climate space as there is a good visual fit between predicted suitable climate space and observed distribution and overlap with SABAP distributions (there is no gross over-prediction - see Figure 2). We created an index of fragmentation based on the sum of polygons of area $>1 \mathrm{~km}^{2}$ together with a correction based on the sum of all polygons (i.e. number of fragments/sum of all climate space).

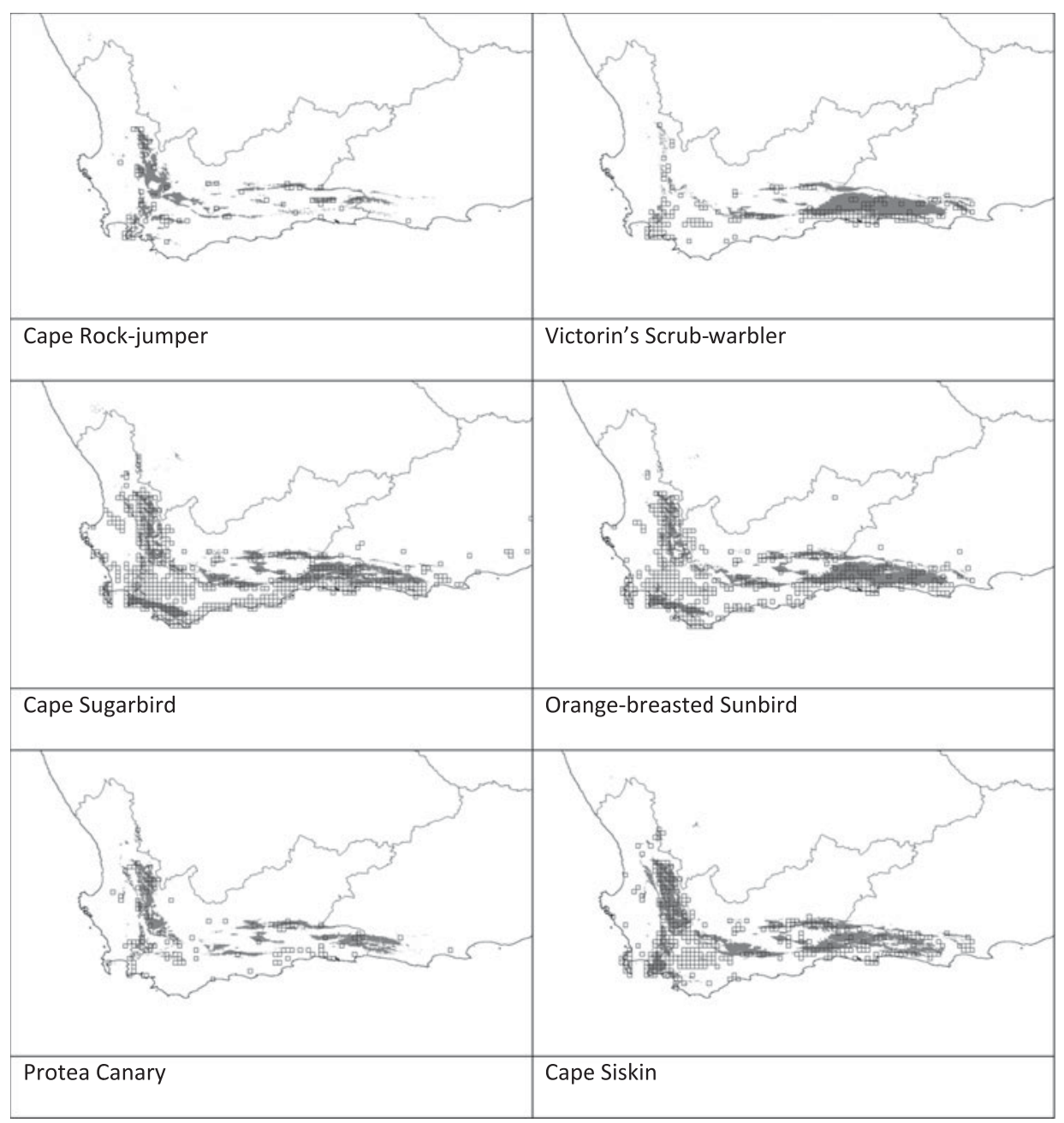

Figure 2. Areas of occupancy (from SABAP atlas data as grid cells) and optimal climatic regions (grey fill) modelled using 19 climatic variables and MaxEnt for six Fynbos endemic bird species. 


\section{Examining the impacts of future climate change on suitable climate space}

We modelled temperature-dependent changes for climate space using BIOCLIM and Diva-Gis (Hijmans et al. 2005a) for +2 and $+4{ }^{\circ} \mathrm{C}$ temperature scenarios as well as scenarios with $50 \%$ and $75 \%$ of current rainfall. For South Africa, the survey points and presence of each species, the mean annual temperature based on background data was extracted from the Worldclim dataset (Hijmans et al. 2005b) following the protocol of Phillips (2005). We plotted histograms of these data and tested for differences of these temperature distributions against that of the survey (which we assume is representative of the Fynbos) for each species using t-tests.

\section{Calculations of area of occupancy and realized range change from atlas data}

Since there is already widespread evidence for increases in temperature across the globe and for South Africa (New et al. 2006), range decreases should already be evident for species given long enough datasets. We compared presence and reporting rates for SABAPI and $\mathrm{SABAP}_{2}$ at the quarter degree grid cell (QDGC) level, as SABAPI was conducted at this scale. Data for these projects consist of lists of birds submitted by citizen scientists by location for the periods 1987 to 1991 (SABAPI) and 2007 to present (SABAP2) (Harrison et al. 1997). This allows comparison between atlas periods for range changes for a roughly 20 year period and for how often a species was recorded in a list (i.e. reporting rate, which is an index of relative abundance). At the time of data access, July 2013, SABAP1 and SABAP2 had coverage of 2,313 and 2,294 QDGCs respectively, with complete coverage between periods of the 182 QDGCs of the Fynbos. Coverage may not necessarily be consistent between periods due to effort and protocol differences: reporting was conducted at a finer scale during $\mathrm{SABAP}_{2}$ (although they are broadly comparable as discussed by Altwegg et al. 2012). Comparisons are more likely to be conservative than to exaggerate increases or decreases (Loftie-Eaton 2014). To determine if there was a systematic bias between datasets for the target species, we also present changes for a further ten species endemic or near endemic to South Africa also present in the Fynbos, although not endemic to the biome. Following initial analysis that showed range contractions for Cape Rock-jumper and Protea Canary, we sent an email to a listserve of $\mathrm{SABAP}_{2}$ contributors $(1,413$ registered, with 426 active in 2014 for all southern Africa) asking for comments on evidence of range contractions.

For each species we calculated the sum of the area of pentads (grid-cell survey units circa $5^{\prime} \times 5^{\prime}$ or roughly $9 \mathrm{~km} \times 9 \mathrm{~km}$ ) from which each species had been reported to $\mathrm{SABAP}_{2}$, including all records. We multiply this value by 81 , the area for a pentad. We regard this as the 'area of occupancy'.

\section{Results}

\section{Density and population estimates}

Density estimates for all Fynbos endemic species were modelled to within the $20 \%$ covariation range, which is a threshold suggesting reasonable results (Marsden 1999). While we comment here on the confidence interval of the mean density for the biome, bird densities are often much higher locally under favourable conditions. Cape Rock-jumper had the lowest density estimates of the endemic bird species (0.56-1.02 ind $/ \mathrm{km}^{2}$; Table 1), and Cape Sugarbird the highest (23.6-30.3). Cape Rock-jumper showed an inverse relationship between density and time since fire categories, while Cape Sugarbird showed a linear increase in density with time since fire indicating a preference for older vegetation (Table 1). Densities for Victorin's Scrub-warbler and Orange-breasted Sunbird were low for the young Fynbos category $(<5$ years since fire $)$, but stable thereafter, suggesting rapid recovery of populations to levels where they are regulated by factors other than fire. Neither of the granivores (Protea Canary and Cape Siskin) showed a consistent trend of density with fire, although Cape Siskin densities were highest in the young Fynbos category ( 33 individuals per $\mathrm{km}^{2}$ ). Population estimates (Table 2) for all species were 
Table 1. Density estimates for the six Fynbos endemic bird species. 'Global' = mean of the densities calculated by vegetation age class (categories represent time since last fire). Not shown here are results for strata of mixed age and for the strata where age was not-applicable. $\mathrm{D}=$ density per age class (individuals $/ \mathrm{km}^{2}$ ). Range $=$ lower to upper $95 \%$ confidence limits. $n=$ the number of group encounters used to calculate these results, and \% CV = percentage covariation of the model fit.

\begin{tabular}{|c|c|c|c|c|c|c|c|c|c|c|c|c|c|c|}
\hline & & & Global & & $<5$ years & & $5-9$ & & $10-14$ & & $15-19$ & & $>20$ & \\
\hline Species & $n$ & $\% \mathrm{CV}$ & D & Range & D & Range & D & Range & D & Range & D & Range & D & Range \\
\hline Cape Rock-jumper & 58 & 15 & 0.75 & $0.56-1.02$ & 1.86 & $1.38-2.5$ & 0.74 & $0.55-1$ & 0.61 & $0.46-0.82$ & 0.22 & $0.16-0.3$ & 0.56 & $0.41-0.76$ \\
\hline Protea Canary & 41 & 18.8 & 9.8 & $6.8-14.3$ & 12.3 & $8.5-18$ & 2.7 & $1.8-3.8$ & 7.8 & $5.4-11.3$ & 12.8 & $8.8-18.6$ & 16.2 & $11.1-23.5$ \\
\hline Cape Siskin & 65 & 18.9 & 15.1 & $10.5-21.9$ & 33.2 & $23-48$ & 14 & $9.6-20.2$ & 16.5 & $11.4-23.9$ & 20.8 & $14.4-30.2$ & 7 & $4.8-10$ \\
\hline Cape Sugarbird & 264 & 6.3 & 26.7 & $23.6-30.3$ & 6.1 & $5.4-6.9$ & 20.8 & $18.5-23.5$ & 32.4 & $28.7-36.6$ & 36.1 & $31.8-41$ & 46.8 & $41.4-52.8$ \\
\hline Orange-breasted Sunbird & 320 & $4 \cdot 7$ & 18.3 & $16.7-20.1$ & 10.3 & $9.4-11.3$ & 20.8 & $19-22.8$ & 21.4 & $19.5-23.5$ & 20.2 & $18.4-22.3$ & 19.6 & $17.9-21.5$ \\
\hline Victorin's Scrub-warbler & 248 & 6.2 & 13.5 & $12-15 \cdot 3$ & 5.2 & $4.6-5.8$ & 20.4 & $18.1-23.1$ & 21.9 & $19.4-24.7$ & 11.1 & $9.8-12.5$ & 19.1 & $16.9-21.6$ \\
\hline
\end{tabular}

Table 2. Area of occupancy (sum of species presence in SABAP2 atlas data * 81) and Climatic space, modelled with MaxEnt, for the six Fynbos endemic bird species. AUC for all models was $>98 \%$. $n$ is the number of points used to model the climate space. Fragmentation is the number of $>0.5 \mathrm{~km}^{2}$ polygons that make up the climate space. Frag/cs is the degree of fragmentation standardized by the climate space. Max fragment is the size of the largest polygon of the modelled climate space. Population estimates is the suitable bioregion area (EOO: $58,126 \mathrm{~km}^{2}$ ) multiplied by global density estimates ranges (Table 1 )

\begin{tabular}{|c|c|c|c|c|c|c|c|c|}
\hline Species & Area of Occupancy & $n$ & Climate space $\left(\mathrm{km}^{2}\right)$ & Conf. & Frag. & Frag/cs & Max fragment $\left(\mathrm{km}^{2}\right)$ & Population (individuals) \\
\hline Cape Rock-jumper & 5,913 & 77 & $10,354(7,671-12,692)$ & $87 \%$ & 203 & 0.020 & 3,480 & $32,55^{1-59,289}$ \\
\hline Victorin's Scrub-warbler & 14,256 & 190 & $14,791(10,073-20,360)$ & $88 \%$ & 254 & 0.017 & 9,528 & $697,512-889,328$ \\
\hline Protea Canary & 8,829 & 76 & $12,843(8,422-16,997)$ & $91 \%$ & 193 & 0.015 & 3,917 & $395,257-831,202$ \\
\hline Cape Siskin & 28,107 & 187 & $22,058(12,601-30,263)$ & $88 \%$ & 225 & 0.010 & 6,366 & $610,323-1,272,959$ \\
\hline Cape Sugarbird & 44,469 & 211 & $21,000(11,871-29,148)$ & $91 \%$ & 371 & 0.018 & 7,158 & $1,371,774-1,761,218$ \\
\hline Orange-breasted Sunbird & 35,316 & 410 & $20,839(16,191-26,322)$ & $89 \%$ & 249 & 0.012 & 9,388 & $970,704-1,168,333$ \\
\hline
\end{tabular}


greater than 10,000 (an IUCN metric for identifying 'Vulnerable' populations), with the lowest estimate for Cape Rock-jumper at 32,00o individuals.

\section{Vulnerability to indirect impacts of climate change}

Here we examine vegetation height effects calculated from 212 plant species or functional groups on group encounter rate of species, as vegetation height is predicted to be reduced under climate change by dry, hot conditions and more frequent fires. Encounters of groups of Cape Rock-jumper and Cape Siskin are negatively correlated with vegetation height - indicative of a preference for low vegetation cover, while Cape Sugarbird, Orange-breasted Sunbird and Victorin's Scrub-warbler are positively correlated with vegetation height (Table 3 ), indicating a preference for tall vegetation which is usually also dominated by Proteaceae. There was a significant difference in vegetation height between dry (north-) and wet (south-facing) slopes, with taller vegetation on the moist, cooler south-facing slopes (dry: $1.4 \pm 1.6 \mathrm{~m}$; wet: $1.7 \pm 1.6$; intermediate: $1.55 \pm 1.3 ; \mathrm{K}=22.5$, $P<0.001, n=886, \mathrm{df}=2$ ). Of the six endemics, the two insectivorous species showed differences in group encounter rates with aspect: Cape Rock-jumper were more frequently encountered on dry slopes (dry: $0.09 \pm 0.3$ grps/point; wet: $0.05 \pm 0.3$; intermediate: $0.07 \pm 0.3 ; \mathrm{K}=7.9, P=0.02$, $n=899, \mathrm{df}=2$ ), while Victorin's Scrub-warbler was more frequently encountered on wet slopes (dry: $0.26 \pm 0.7$; wet: $0.4 \pm 0.8$; intermediate: $0.3 \pm 0.7 ; \mathrm{K}=14.1, P=0.001, n=899, \mathrm{df}=2$ ).

\section{Suitable climate space}

Average annual temperature of the Fynbos (as defined by the background points of this survey) is $2.7-3{ }^{\circ} \mathrm{C}$ degrees cooler than a random selection of background temperatures from the rest of South Africa (Fynbos: $14.3 \pm 1.6^{\circ} \mathrm{C}$, South Africa: $17.1 \pm 2.5 ; \mathrm{t}=49.7, P<0.001$ ). Within the Fynbos, the background mean annual temperatures of points from which a species was recorded was lower for two of the endemics compared to the background temperature of the Fynbos: Cape Rock-jumper $(\mathrm{t}=-10.44, P<0.001)$ and Cape Siskin $(\mathrm{t}=-3.6, P<0.001)$, while for Protea Canary this trend was not significant ( $\mathrm{t}=-1.9, P=0.055$; Table 4; Figure 3 ).

All mapped predictions of suitable climatic space were congruent with published maps for the species distributions and no climatic envelope is greater than the 'extent of occurrence' (Table 2, Figure 2). Cape Rock-jumper and Protea Canary had the smallest mapped climatic space; and Cape Siskin and Orange-breasted Sunbird had the largest. Cape Rock-jumper also had the highest fragmentation index relative to the fragmentation index mean for all the endemics (Cape Rock-jumper: 0.02; mean: 0.015), and the smallest maximum fragment size $\left(3,480 \mathrm{~km}^{2}\right.$; mean 6,640 $\left.\mathrm{km}^{2}\right)$.

Table 3. Modelling the impacts of climate change: BIOCLIM results for suitable current climatic space (number of $10^{\prime}$ cells), together with predicted suitable climatic space under scenarios of $2{ }^{\circ} \mathrm{C}$ and $4{ }^{\circ} \mathrm{C}$ increase in temperature (rainfall constant) as well as decrease in rainfall (to $75 \%$ and $50 \%$ of current) with temperature held constant. We also include the average of five models of estimated range predicted to remain for each species from Huntley and Barnard (2012) for the end of the century. Correlation coefficients between group encounters and vegetation height for 886 point count surveys are presented for Vegetation (positive correlations indicate increasing group encounters with increasing average vegetation height).

\begin{tabular}{|c|c|c|c|c|c|c|c|c|}
\hline \multirow[b]{2}{*}{ Species } & \multicolumn{3}{|c|}{ Temperature } & \multicolumn{2}{|l|}{ Rain } & \multirow[b]{2}{*}{ Huntley/Barnard } & \multicolumn{2}{|c|}{ Vegetation } \\
\hline & Current & $+2^{\circ} \mathrm{C}$ & $+4^{\circ} \mathrm{C}$ & $75 \%$ & $50 \%$ & & rs & $P$ \\
\hline Cape Rock-jumper & 138 & 32 & o & 101 & 41 & $38 \%$ & -0.21 & $<0.001$ \\
\hline Victorin's Scrub-warbler & 156 & 32 & o & 102 & 39 & $28 \%$ & +0.21 & $<0.001$ \\
\hline Protea Canary & 98 & 27 & o & 60 & 20 & $40 \%$ & 0.02 & 0.51 \\
\hline Cape Siskin & 214 & 66 & 4 & 165 & 78 & $42 \%$ & -0.08 & 0.02 \\
\hline Cape Sugarbird & 302 & 145 & 14 & 246 & 134 & $38 \%$ & +0.25 & $<0.001$ \\
\hline Orange-breasted Sunbird & 317 & 154 & 14 & 253 & 142 & $37 \%$ & +0.08 & 0.02 \\
\hline
\end{tabular}


Table 4. Training gain of final MaxEnt models: the contribution of climatic variables to estimated climate space (Table 3) with the top five contributing variables in bold. AMT is the mean of 'annual mean temperature' for points where a species is recorded, together with P values for how these differ from the mean AMT of all survey points. Inflection points for increasing rates of evaporative water loss from Milne (2014) are also provided (EWL).

\begin{tabular}{|c|c|c|c|c|c|c|}
\hline $\begin{array}{l}\text { Variables that contribute individually } \\
\text { to the climate models }\end{array}$ & $\begin{array}{l}\text { Cape } \\
\text { Rock-jumper }\end{array}$ & $\begin{array}{l}\text { Protea } \\
\text { Canary }\end{array}$ & $\begin{array}{l}\text { Cape } \\
\text { Siskin }\end{array}$ & $\begin{array}{l}\text { Cape } \\
\text { Sugarbird }\end{array}$ & $\begin{array}{l}\text { Orange- } \\
\text { breasted } \\
\text { Sunbird }\end{array}$ & $\begin{array}{l}\text { Victorin's } \\
\text { Scrub-warbler }\end{array}$ \\
\hline Bio_I = Annual Mean Temperature & 1.86 & 1.06 & 1.03 & 0.94 & 0.88 & 0.93 \\
\hline Bio_2 = Mean Diurnal Range & 0.74 & 0.61 & 0.67 & 0.80 & 0.77 & 0.98 \\
\hline Bio_3 = Isothermality & 0.36 & 0.42 & 0.41 & 0.39 & 0.40 & 0.70 \\
\hline $\begin{array}{l}\text { Bio_4 }=\text { Temperature Seasonality } \\
\text { Bio_5 }=\text { Max Temperature of Warmest }\end{array}$ & 0.66 & 0.61 & 0.63 & 0.72 & 0.72 & 0.96 \\
\hline $\begin{array}{l}\text { Month } \\
\text { Bio_6 = Min Temperature of Coldest }\end{array}$ & 1.31 & 0.58 & 0.75 & 0.92 & 0.86 & 1.12 \\
\hline Month & 0.11 & 0.36 & 0.19 & 0.28 & 0.29 & $0.4^{2}$ \\
\hline $\begin{array}{l}\text { Bio_7 }=\text { temperature Annual Range } \\
\text { Bio_8 }=\text { Mean Temperature of Wettest }\end{array}$ & 0.76 & 0.71 & 0.67 & 0.78 & 0.76 & 1.00 \\
\hline $\begin{array}{l}\text { Quarter } \\
\text { Bio_9 = Mean Temperature of Driest }\end{array}$ & 1.86 & 1.47 & 1.48 & 1.47 & 1.41 & 1.39 \\
\hline $\begin{array}{l}\text { Quarter } \\
\text { Bio_1o = Mean Temperature of }\end{array}$ & 0.37 & 0.44 & 0.31 & 0.39 & 0.40 & 0.28 \\
\hline $\begin{array}{l}\text { Warmest Quarter } \\
\text { Bio_II = Mean Temperature of }\end{array}$ & 1.93 & 1.02 & 1.12 & 1.22 & 1.15 & 1.29 \\
\hline Coldest Quarter & 0.92 & 0.49 & 0.36 & 0.23 & 0.23 & 0.20 \\
\hline $\begin{array}{l}\text { Bio_12 }=\text { Annual Precipitation } \\
\text { Bio_13 }=\text { Precipitation of Wettest }\end{array}$ & 0.28 & 0.33 & 0.36 & 0.33 & 0.32 & 0.39 \\
\hline $\begin{array}{l}\text { Month } \\
\text { Bio_14 = Precipitation of Driest }\end{array}$ & 0.25 & 0.26 & 0.44 & 0.47 & 0.45 & 0.55 \\
\hline Month & 1.26 & 0.88 & 1.24 & 1.42 & 1.37 & 2.11 \\
\hline $\begin{array}{l}\text { Bio_15 }=\text { Precipitation of Seasonality } \\
\text { Bio_16 }=\text { Precipitation of Wettest }\end{array}$ & 1.27 & 1.30 & 1.51 & 1.58 & 1.53 & 2.32 \\
\hline $\begin{array}{l}\text { Quarter } \\
\text { Bio_17 = Precipitation of Driest }\end{array}$ & 0.32 & 0.29 & 0.52 & 0.52 & 0.51 & 0.63 \\
\hline $\begin{array}{l}\text { Quarter } \\
\text { Bio_18 = Precipitation of Warmest }\end{array}$ & 1.37 & 1.00 & 1.31 & 1.48 & 1.43 & 2.09 \\
\hline $\begin{array}{l}\text { Quarter } \\
\text { Bio_19 = Precipitation of Coldest }\end{array}$ & 0.56 & 0.56 & 0.64 & 0.59 & 0.60 & 0.67 \\
\hline Quarter & 2.06 & 1.88 & 1.95 & 1.96 & 1.89 & 2.07 \\
\hline $\begin{array}{l}\text { Mean annual temperature } \\
\text { Standard deviation of mean annual }\end{array}$ & 12.39 & 13.93 & 13.74 & 14.39 & 14.23 & 14.46 \\
\hline $\begin{array}{l}\text { temperature } \\
P \text { values for test against difference of }\end{array}$ & 1.49 & 1.36 & 1.77 & 1.38 & 1.47 & 1.45 \\
\hline species AMT against the Fynbos & 0.00 & 0.06 & 0.00 & 0.22 & 0.86 & 0.08 \\
\hline mean inflection point for EWL & -10.44 & -1.90 & -3.60 & 1.22 & -0.17 & 1.75 \\
\hline$\left({ }^{\circ} \mathrm{C}\right)$ from Milne $(201$ & 31.20 & 33.50 & 35.60 & 34.60 & 36.70 & 34.70 \\
\hline
\end{tabular}

Table 4 lists the contribution of each climatic variable to the prediction of the climatic space. For only Protea Canary and Cape Rock-jumper was there evidence that temperaturerelated variables were important in predicting climatic space. Both mean annual temperature and the mean temperature of the warmest quarter of the year were limiting for these species, but none of the other species. There is a significant negative correlation between training gain scores (how well the final model accounts for test data locations) for the contribution of the mean annual temperature variable to mapped climatic space and mean evaporative water 


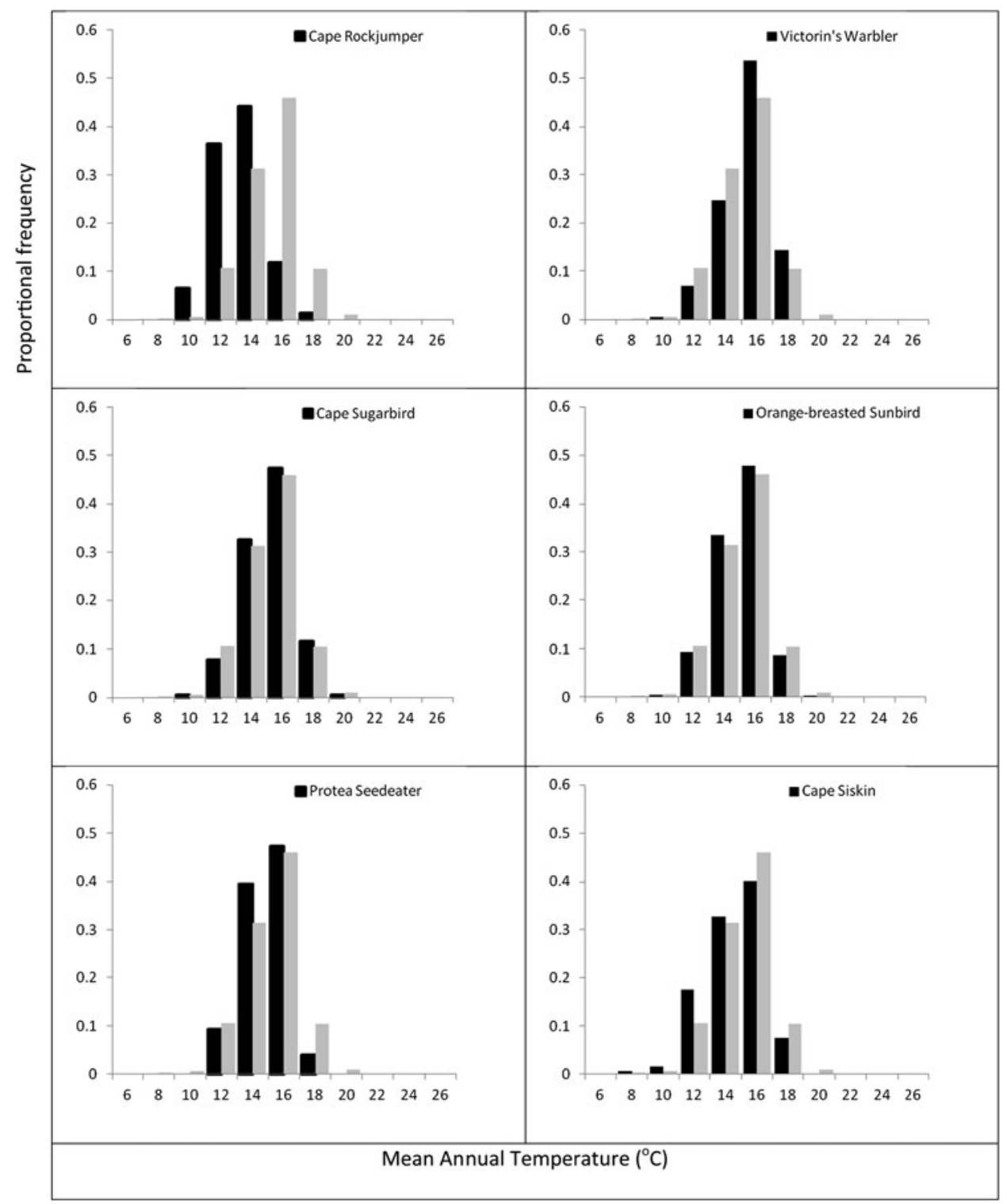

Figure 3. Histograms of frequency of occurrence against annual mean temperatures of the six Fynbos endemic bird species compared to mean annual temperature of the survey, with the point values extracted from the Bior variable of the Worldclim database at $0.5^{\prime}$ scale.

loss inflection points from Milne (2014) ( $\mathrm{rs}=-0.83, P=0.04, n=6$ ) i.e. higher scores for the role of mean annual temperature in determining the climate space are associated with species that display lower thermal tolerance. Other major predictors (as measured by model training gain) are better explanatory variables of the presence of the Fynbos biome: e.g. three top predictors for all endemics were temperature of wettest quarter, precipitation of driest quarter and precipitation of coldest quarter (Table 4) which conform to the description of the Fynbos as a predominantly winter rainfall region. 
Table 5. Realised range changes: SABAPI and SABAP2 occurrence as the number of Quarter Degree Grid Cells (QDGCs), with the percentage change between atlas periods and percentage change in reporting rate.

\begin{tabular}{lcccc}
\hline & QDGCs & & \\
\cline { 2 - 4 } Species & SABAP1 & SABAP2 & Change & Reporting Rate \\
\hline Cape Rock-jumper & 56 & 38 & $-32 \%$ & $-31 \%$ \\
Victorin's Scrub-warbler & 69 & 66 & $-4 \%$ & $13 \%$ \\
Protea Canary & 81 & 55 & $-32 \%$ & $-32 \%$ \\
Cape Siskin & 141 & 115 & $-18 \%$ & $-5 \%$ \\
Cape Sugarbird & 168 & 143 & $-15 \%$ & $7 \%$ \\
Orange-breasted Sunbird & 152 & 132 & $-13 \%$ & $-10 \%$ \\
Other South African endemic bird species & & & & \\
Cape Bulbul Pycnonotus capensis & 286 & 278 & $-3 \%$ & $30 \%$ \\
Cape Grassbird Sphenoeacus afer & 553 & 503 & $-9 \%$ & $35 \%$ \\
Large-billed Lark Galerida magnirostris* & 708 & 526 & $-26 \%$ & $25 \%$ \\
Knysna Warbler Bradypterus sylvaticus & 44 & 42 & $-5 \%$ & $47 \%$ \\
Southern Tchagra Tchagra tchagra & 323 & 274 & $-15 \%$ & $20 \%$ \\
Swee Waxbill Coccopygia melanotis & 396 & 278 & $-30 \%$ & $5 \%$ \\
Cape Weaver Ploceus capensis & 960 & 830 & $-14 \%$ & $24 \%$ \\
Southern Double-collared Sunbird Cinnyris chalybeus & 713 & 575 & $-19 \%$ & $23 \%$ \\
Knysna Woodpecker Campethera notate & 126 & 117 & $-7 \%$ & $106 \%$ \\
Cape Spurfowl Pternistis capensis & 245 & 225 & $-8 \%$ & $18 \%$ \\
Pied Starling Spreo bicolour & 1196 & 953 & $-20 \%$ & $-17 \%$ \\
Karoo Prinia Prinia maculosalhypoxantha** & 1029 & 859 & $-17 \%$ & $16 \%$ \\
\hline
\end{tabular}

${ }^{*}$ There is incomplete coverage during SABAP2 of historical ranges (SABAPI) of these species in the Northern Cape province at the time of this manuscript preparation, so range change declines presented for these species are likely unrealistic.

${ }^{* *}$ Due to a species split between atlas periods of the Spotted Prinia, the presented data for SABAP2 consists of the combined range of the two new species - Karoo Prinia and Drakensberg Prinia

\section{Future climate change impacts}

Climatic space changes for all the Fynbos endemic bird species under future climate change scenarios are unfavourable, and are influenced most strongly by temperature increases compared to changes in precipitation (Table 3). No suitable climatic space remains for Cape Rock-jumper, Protea Canary and Victorin's Scrub-warbler under a scenario of warming of $4{ }^{\circ} \mathrm{C}$ - a 'likely as not' scenario for the end of this century according for Representative Concentration Pathway climate model simulation RCP8.5 (IPCC 2013).

\section{Areas of occupancy and range changes}

Four Fynbos endemics showed a negative trend in reporting rates, compared to only one of the 12 other South African endemics. Cape Rock-jumper and Protea Canary were recorded from $>30 \%$ fewer QDGCs between SABAP1 and SABAP2 (Table 5), which present some of the greatest range contractions of the suite of 18 passerine species examined here. Both these species also show a $>30 \%$ decrease in reporting rate. Responses on preliminary results were received from six contributors to the atlas survey, which suggested disappearance of Cape Rock-jumper at the southern and eastern extremes of its range, together with one site in the centre of its range which is a mountain surrounded by Karoo (Gamkaberg) where the highest peaks are associated with the lowest levels of occurrence in surrounding mountains with greater elevation extent. We received no responses that confirmed evidence for range contraction of Protea Canary, although one response suggested the species had not been reported for the northern sections of its range. By contrast, Victorin's Scrub-warbler showed the smallest contraction difference in reported area $(-4 \%)$ for the endemics, and also showed a $13 \%$ increase in reporting rate. 
Areas of occupancy based on reported areas of occurrence from atlas survey data are all below maximum extent of occurrence for these species in the biome. For three species (Cape Sugarbird, Orange-breasted Sunbird and Cape Siskin) the area of occupancy is well above estimated suitable climatic space suggesting climatic variables are not limiting in determining their ranges. For Cape Rock-jumper, the area of occupancy measure is likely an under-estimate as rugged mountain tops are likely to be under-surveyed by atlas contributors.

\section{Discussion}

IUCN criteria for categorisation of threatened status for a species rely on information on population sizes and trends, range size and integrity (degree of fragmentation), and threats leading to population declines. We have presented for the first time a detailed accounting of these aspects for the six passerine birds that occur only in the threatened Fynbos biome, a global biodiversity hotspot. While these are currently listed as species of Least Concern, at the time of this assessment two species - the Cape Rock-jumper and Protea Canary - meet criteria to be listed as species of conservation concern. Protea Canary and Cape Rock-jumper occur in regions that are on average cooler than the mean annual temperature for the Fynbos. Four species - Cape Sugarbird, Orangebreasted Sunbird, Victorin's Scrub-warbler and Cape Siskin are found across most of the biome, have large populations and show relatively stable trends in range and population metrics between atlas periods.

The high mobility of nectarivores as they track the flowering phenology of their food plants may contribute to their above-expected occupancy of suitable climatic space compared to the relatively sedentary Rock-jumper. The nectarivores and Cape Siskin might be able to tolerate short, localised periods of high temperatures as they move around the region and thus be more buffered against the effects of climate change, while Rock-jumper is saddled with potentially permanent heat stress if it does not move seasonally or altitudinally.

Causes of declines in reported ranges for Cape Rock-jumper and Protea Canary over a relatively short period (c.2O years) are unlikely to be due to direct landscape transformation through agriculture. Arable land in the Fynbos had already been converted well before the first atlas period (Cowling et al. 1986). Core habitats are well protected within a large network of provincial nature reserves. While alien vegetation is a growing threat to Fynbos integrity, a well-funded paymentfor-ecological-services programme (Working for Water) tackling alien vegetation has been very active in the Fynbos biome over the last decade (Turpie et al. 2008) and there has been extensive introduction of biocontrol agents. Declines are also unlikely to be due to protocol differences between atlas periods, as the finer resolution of $\mathrm{SABAP}_{2}$ has encouraged atlas participants to visit more inaccessible regions of QDGCs (Loftie-Eaton 2014). As the rocky outcrops habitats of the Cape Rockjumper are mostly inaccessible, we would thus expect an increase in reporting rates. On the other hand, should a QDGC with a single site for a special species like Cape Rock-jumper fall into only one pentad then it is possible it may have been visited by most $\mathrm{SABAP}_{1}$ observers, but the species would be recorded in only one of the nine pentads of the QDGC in SABAP2, resulting in smaller reporting rates in SABAP2. However, a species where this effect would most likely been observed would be the Knysna Warbler which is restricted to small and scattered forest patches, but for which range was relatively stable, and where reporting rate showed a dramatic increase.

Protea Canaries are found in large numbers in areas of recently burnt, former mature Fynbos associated with the release of large numbers of stored seeds from Protea species, but breed in mature Fynbos (Lee and Barnard 2014). With fire occurring at greater frequencies (Southey 2009) and over wider areas (Kraaij et al. 2012), there may be a decrease in the juxtaposition of available food and nesting resources for this species. In addition, granivorous birds acquire little water from their food and are thus likely to pay greater evaporative water loss costs at high temperatures when water resources are limited (Bartholomew and Cade 1963). Protea Canaries could thus suffer additional ecological stress with increasing ambient temperatures. 
For Cape Rock-jumper, range contractions are likely to be related to physiological limits on thermoregulation (Milne 2014), as the indirect impacts of climate change on vegetation structure should favour this species - it is found in association with shorter vegetation and on dry (northfacing) slopes. However, Cape Rock-jumper is notably absent from the Fynbos-Karoo interface, where dry vegetation structure and rocky outcroppings would suggest habitat suitability. Since Cape Rock-jumper is a generalist insectivore, it is unlikely that range limitation is associated with food limitation - especially as increasing temperatures favour invertebrate activity in the Fynbos (Lee and Barnard unpubl. data). We cannot rule out the possibility of competitive exclusion by the encroachment of other insectivores due to advancement of suitable environments, but we do not observe other insectivorous species in areas previously occupied by Cape Rock-jumper. The reality is that significant biological effects of climate change are already being manifested as extinctions (Pounds et al. 1999, Thomas et al. 2006) and as rapid shifts in the distributions of species inhabiting latitudes ranging from polar to equatorial (Chen et al. 2011). Further, recent experimental ecophysiology work on Cape Rock-jumper and other species by Milne (2014) has demonstrated that Cape Rock-jumper is particularly unable to deal with warmer temperatures above $31.2^{\circ} \mathrm{C}$ without incurring significant heat stress through high evaporative water loss. The $0.5-1^{\circ} \mathrm{C}$ increase in temperatures across the Fynbos over the last half century represents a 100-200 $\mathrm{m}$ contraction of vertical space (based on mean lapse rates) for this species.

Based on preliminary results from this study, Cape Rock-jumper has been nationally uplisted in South Africa to 'Near Threatened' (Taylor et al. 2014). This species meets two main IUCN criteria for 'Vulnerable' status: A2 and B2. Criterion A2 can be invoked when 'an observed, estimated, inferred or suspected population size reduction of $30 \%$ has occurred over the last 10 years..., where the reduction or its causes may not have ceased OR may not be understood OR may not be reversible' which can be justified with results from declines in the SABAP data, together with the link to climate change. It appears that the area of occupancy (and suitable climate space) is well below $20,000 \mathrm{~km}^{2}$, which combined with severe fragmentation (as presented here and in an earlier review of disjointed reporting sites from atlas data in Lee and Barnard (2012) and inferred population declines, makes the species 'Vulnerable' under Red List criterion $\mathrm{B}_{2}$.

Protea Canary may also meet criterion $\mathrm{A}_{2}$, with an apparent decline between SABAP1 and $\mathrm{SABAP}_{2}$ of $>30 \%$, although issues of fragmentation appear to be less severe for this species. However, patterns of distribution in relation to climatic variables are not as clear as for Cape Rock-jumper, and an element of doubt exists with respect to SABAP data quality for this fairly cryptic species.

Projections on the potential impacts of a warming climate presented here infer that Cape Rockjumper, Protea Canary and Victorin's Scrub-warbler meet Red List criteria for 'Vulnerable' E (Quantitative analysis showing the probability of extinction in the wild is at least 10\% within 100 years). Even so, a cautious approach to predicting climate impacts is required, inspired by observations that biotic interactions can overwhelm the direct impacts of climate (Suttle et al. 2007) and that climate change occurs against a complex background of land-use change and habitat fragmentation that must also be considered (Sala et al. 2000). However, the exposed rocky environment in which Cape Rock-jumper occurs provides this species with little of the thermal buffering that may result from tall structured habitats. For instance, while Victorin's Scrub-warbler has a small range and is modelled to decline due to changes in climate, its use of lower strata in rank habitats will most likely buffer it from direct temperature increases, and this may be the reason no range contraction has yet been observed according to SABAP data. Species density data for Victorin's Scrub-warbler suggests that as long as fire return intervals remain greater than five years, so allowing vegetation to recover, climate change impacts on habitat suitability may be mitigated.

Modelling of paleoclimates suggests that greater Western Cape region was previously more suitable for the persistence of the Fynbos endemic bird species compared to the present, even without anthropogenic influences (Huntley et al. 2013). There are several examples of species 
limited by climate space, including Ethiopian Bush-crow Zavattariornis stresemanni (Donald et al. 2012) and Rock Ptarmigan Lagopus muta helvetica in the Alps (Revermann et al. 2012). The latter, while still classified as Least Concern globally due to extensive boreal populations, is classified as 'Near Threatened' at the national level in Switzerland due to the $30 \%$ decrease from permanent monitoring sites (Keller et al. 2010). It is thus our recommendation that Cape Rock-jumper be uplisted from 'Least Concern' to 'Vulnerable', while Protea Canary be uplisted to 'Near Threatened'. With the exception of Cape Sugarbird and Orange-breasted Sunbird, there is very little published on the ecology of the Fynbos endemics. Targeted research should include repeat surveys along an altitudinal gradient at a few sites over a number of years combined with behavioural studies to identify consequences of heat-stress mitigation strategies on reproductive ecology. This information is much needed in order to create climate-sensitive management plans for these species.

\section{Acknowledgements}

Peter Ryan, Graeme Cumming, Arjun Amar and Phil Hockey advised on the survey design. Sunil Kumar provided advice on GIS and MaxEnt methods. Les Underhill, Michael Brooks and the ADU team (University of Cape Town) are thanked for access to SABAP comparison tools. The impressive SABAP and SABAP2 datasets would not exist without huge effort by the citizen science atlas community, coordinated by Les Underhill and Doug Harebottle. Thanks to Dale Wright at BirdLife South Africa for various support. This research was conducted under CapeNature permit 0056-AAAo41-00oo1 and Eastern Cape Parks and Tourism Agency permit RA o116. Tom Barry, Kevin Shaw, Rob Simmons, Wim de Klerk, Paul Martin, Yvonne Craig, Derek and Merle Chalton commented on SABAP2 range contractions for Cape Rock-jumper and Protea Canary. Initial drafts of this manuscript were kindly improved by Susan Cunningham and two anonymous reviewers. Funding for this study was received from BirdLife South Africa, the Percy FitzPatrick Institute of African Ornithology, and a National Research Foundation (NRF) grants BSC20100818000016498 and CPR2010041600001 to Res Altwegg and IFR2011041800032 to Phoebe Barnard.

\section{References}

Altwegg, R., Broms, K., Erni, B., Barnard, P., Midgley, G. F. and Underhill, L. G. (2012) Novel methods reveal shifts in migration phenology of barn swallows in South Africa. Proc. R Soc. B: Biol. Sci. 279: 1485-1490.

Barnes, K. N. (1998) The important bird areas of southern Africa. Johannesburg: BirdLife South Africa.

Bartholomew, G. A. and Cade, T. J. (1963) The water economy of land birds. The Auk 80: 504-539.

BirdLife International (2013) Endemic Bird Area factsheet: Cape fynbos. Downloaded from http://www.birdlife.org on 03/07/2013.

Buckland, S. T., Anderson, D. R., Burnham, K. P. and Laake, J. L. (2005) Distance sampling: Wiley Online Library.

Buckland, S. T., Marsden, S. J. and Green, R. E. (2008) Estimating bird abundance: making methods work. Bird Conserv. Internatn. 18: S91-Si08.

Chalmandrier, L., Midgley, G. F., Barnard, P. and Sirami, C. (2013) Effects of time since fire on birds in a plant diversity hotspot. Acta Oecol. 49: 99-106.

Chen, I. C., Hill, J. K., Ohlemüller, R., Roy, D. B. and Thomas, C. D. (2011) Rapid range shifts of species associated with high levels of climate warming. Science 333: 1024-1026.

Cowling, R. M. (1995) Fynbos: South Africa's unique floral kingdom. Cape Town: University of Cape Town.

Cowling, R. M., Pierce, S. and Moll, E. (1986) Conservation and utilisation of South Coast Renosterveld, an endangered South African vegetation type. Biol. Conserv. 37: 363-377.

Cowling, R. M., Rundel, P. W., Lamont, B. B., Arroyo, M. K. and Arianoutsou, M. (1996) 
Plant diversity in Mediterranean-climate regions. Trends. Ecol. Evol. 11: 362-366.

Cunningham, S. J., Martin, R. O., Hojem, C. L. and Hockey, P. A. (2013) Temperatures in excess of critical thresholds threaten nestling growth and survival in a rapidlywarming arid savanna: a study of common fiscals. PloS ONE 8: e74613.

Donald, P. F., Gedeon, K., Collar, N. J., Spottiswoode, C. N., Wondafrash, M. and Buchanan, G. M. (2012) The restricted range of the Ethiopian Bushcrow Zavattariornis stresemanni is a consequence of high reliance on modified habitats within narrow climatic limits. J. Ornithol. 153: 1031-1044. Du Plessis, K. L., Martin, R. O., Hockey, P. A. R., Cunningham, S. J. and Ridley, A. R. (2012) The costs of keeping cool in a warming world: implications of high temperatures for foraging, thermoregulation and body condition of an arid-zone bird. Global Change Biol. 18: 3063-3070.

Fewster, R. M., Buckland, S. T., Burnham, K. P., Borchers, D. L., Jupp, P. E., Laake, J. L. and Thomas, L. (2009) Estimating the encounter rate variance in distance sampling. Biometrics 65: 225-236.

Foden, W. B., et al. (2013) Identifying the world's most climate change vulnerable species: A systematic trait-based assessment of all birds., amphibians and corals. PLOS ONE 8: e65427.

Fraser, M. (1997a) Victorin's Warbler. P. 251 in J. A. Harrison, D. G. Allan, L. G. Underhill, M. Herremans, A. J. Tree, V. Parker and C. J. Brown, eds. The atlas of Southern African birds: Volume 2: Passerines. Johannesburg: BirdLife South Africa.

Fraser, M. (1997b) Cape Siskin. Pp. 658-659 in J. A. Harrison, D. G. Allan, L. G. Underhill, M. Herremans, A. J. Tree, V. Parker and C. J. Brown, eds. The atlas of Southern African birds: Volume 2: Passerines. Johannesburg: Birdlife South Africa.

Harrison, J. A., Allan, D. G., Underhill, L. G., Herremans, M., Tree, A. J., Parker, V. and Brown, C. J., eds. (1997) The Atlas of southern African birds. Vols. 1 \& 2. Johannesburg: BirdLife South Africa.

Hijmans, R., Guarino, L., Jarvis, A., O'Brien, R., Mathur, P., Bussink, C., Cruz, M., Barrantes, I. and Rojas, E. (2005a) Diva-GIS version 7.5.
Published on the internet http://divagis.org.

Hijmans, R. J., Cameron, S. E.,Parra, J. L., Jones, P. G. and Jarvis, A. (2005b). Very high resolution interpolated climate surfaces for global land areas. Internatn. J. Climatol. 25: $1965-1978$.

Huntley, B. and Barnard, P. (2012) Potential impacts of climatic change on southern African birds of fynbos and grassland biodiversity hotspots. Divers. Distrib. 18: 769-781.

Huntley, B., Allen, J. R. M., Barnard, P., Collingham, Y. C. and Holliday, P. R. (2013) Species distribution models indicate contrasting late-Quaternary histories for Southern and Northern Hemisphere bird species. Global Ecol. Biogeogr. 22: 277-288.

IPCC (2013) Summary for policymakers. In: Climate Change 2013: The physical science basis. Contribution of working group I to the fifth assessment report of the Intergovernmental Panel on Climate Change. (T. F. Stocker, D. Qin, G.-K. Plattner, M. Tignor, S. K. Allen, J. Boschung, A. Nauels, Y. Xia, V. Bex and P. M. Midgley, eds.). Cambridge, UK and New York, USA: Cambridge University Press.

Keller, V., Gerber, A., Schmid, H., Volet, B. and Zbinden, N. (2010) Rote Liste Brutvogel. Gefahrdete Arten der Schweiz, Stand 2010. Bern, Switzerland: Bundesamt fur Umwelt und Schweizerische Vogelwarte. Sempach. Umwelt-Vollzug Nr. 1019.

Kemper, J., Cowling, R. M. and Richardson, D. M. (1999) Fragmentation of South African renosterveld shrublands: effects on plant community structure and conservation implications. Biol. Conserv. 90: 103-111.

Klausmeyer, K. R. and Shaw, M. R. (2009) Climate change, habitat loss, protected areas and the climate adaptation potential of species in Mediterranean ecosystems worldwide. PLOS ONE 4: e6392.

Kraaij, T., Cowling, R. M. and van Wilgen, B. W. (2012) Lightning and fire weather in eastern coastal fynbos shrublands: seasonality and long-term trends. Internatn. J. Wildland Fire 22: 288-295.

Kruger, A. and Sekele, S. (2013) Trends in extreme temperature indices in South Africa: 1962-2009. Internatn. J. Climatol. 33: 661-676. 
Lee, A. T. K. and Barnard, P. (2012) Endemic Fynbos avifauna: comparative range declines a cause for concern. Ornithol. Observations 3: 19-28.

Lee, A. T. K. and Barnard, P. (2014) Aspects of the ecology and morphology of the Protea seedeater Crithagra leucopterus, a littleknown Fynbos endemic. African Zoology 49: 295-300.

Loftie-Eaton, M. (2014) Geographic range dynamics of South Africa's bird species. MSc dissertation, University of Cape Town, South Africa.

Maclean, G. (1993) Roberts' birds of Southern Africa. Cape Town: John Voelcker Bird Book Fund.

Marsden, S. J. (1999) Estimation of parrot and hornbill densities using a point count distance sampling method. Ibis 141: 377-390.

Midgley, G., Hannahm, L., Millar, D., Rutherford, M. and Powrie, L. (2002) Assessing the vulnerability of species richness to anthropogenic climate change in a biodiversity hotspot. Global Ecol. Biogeogr. 11: 445-451.

Midgley, G. F., Reeves, G. and Klak, C. (2005) Late Tertiary and Quaternary climate change and centers of endemism in the southern African flora. Phylogeny Conserv. 19: 230-242.

Milewski, A. (1976) Feeding ecology and habitat of the Protea Seedeater. PhD dissertation, University of Cape Town.

Milne, R. (2014) Physiological tolerances of high temperatures in Fynbos birds: implications for climate change. MSc dissertation, University of Cape Town.

Monadjem, A., Virani, M. Z., Jackson, C. and Reside, A. (2013). Rapid decline and shift in the future distribution predicted for the endangered Sokoke scops owl Otus ireneae due to climate change. Bird Conserv. Internatn. 23: 247-258.

Mucina, L., and Rutherford, M. C. (2006) The vegetation of South Africa, Lesotho and Swaziland. Pretoria, South Africa: South African National Biodiversity Institute. Strelitzia 19.

Myers, N., Mittermeier, R. A., Mittermeier, C. G., da Fonseca, G. A. B. and Kent, J. (2000) Biodiversity hotspots for conservation priorities. Nature 403: 853 .
New, M., Hewitson, B., Stephenson, D. B., Tsiga, A., Kruger, A., Manhique, A., Gomez, B., Coelho, C. A., Masisi, D. N. and Kululanga, E. (2006) Evidence of trends in daily climate extremes over southern and west Africa. J. Geophys. Res. Atmospheres (1984-2012): 111.

Olson, D. M. and Dinerstein, E. (2002) The Global 200: Priority ecoregions for global conservation. Ann. Mo. Bot. Gard. 89: 199-224.

Phillips, S. (2005) A brief tutorial on Maxent. Florham Par, NJ: AT\&T Labs Research.

Phillips, S. J., Dudík, M. and Schapire, R. E. (2004) A maximum entropy approach to species distribution modeling. Pages 83 . Proceedings of the twenty-first international conference on Machine learning. Neew York: ACM.

Pounds, J. A., Fogden, M. P. L. and Campbell, J. H. (1999) Biological response to climate change on a tropical mountain. Nature 398: 611-615.

Revermann, R., Schmid, H., Zbinden, N., Spaar, R. and Schröder, B. (2012) Habitat at the mountain tops: how long can Rock Ptarmigan (Lagopus muta helvetica) survive rapid climate change in the Swiss Alps? A multi-scale approach. J. Ornithol. 153: 891-905.

Sala, O. E., Chapin, F. S., Armesto, J. J., Berlow, E. and Bloomfield, J. (2000) Biodiversity global biodiversity scenarios for the year 2100. Science 287: 1770-1774.

Sekercioglu, C. H., Schneider, S. H., Fay, J. P. and Loarie, S. R. (2008) Climate change, elevational range shifts, and bird extinctions. Conserv. Biol. 22: 140-150.

Siegfried, W. and Crowe, T. (1983) Distribution and species diversity of birds and plants in Fynbos vegetation of Mediterraneanclimate zone, South Africa. Pages 403-416 in F. di castri and H. A. Mooney, eds. Mediterranean-type ecosystems. BerlinHeidelberg: Springer.

Simmons, R. E., Barnard, P., Dean, W., Midgley, G. F., Thuiller, W. and Hughes, G. (2004). Climate change and birds: Perspectives and prospects from southern Africa. Ostrich 75: 295-308.

Southey, D. (2009) Wildfires in the Cape Floristic Region: Exploring vegetation and 
weather as drivers of fire frequency. MSc Dissertation, Department of Botany, University of Cape Town, South Africa.

Suttle, K. B., Thomsen, M. A. and Power, M. E. (2007) Species interactions reverse grassland responses to changing climate. Science 315: 640-642.

Taylor, M. R., Peacock, D. S. and Wanless, R. M. 2014. The Eskom Red Data Book of birds of South Africa, Lesotho and Swaziland. Johannesburg: BirdLife South Africa.

Thomas, C. D., Franco, A. M. A. and Hill, J. K. (2006) Range retractions and extinction in the face of climate warming. Trends Ecol. Evol. 21: 415-416.

Thomas, L., Buckland, S. T., Rexstad, E. A., Laake, J. L., Strindberg, S., Hedley, S. L., Bishop, J. R., Marques, T. A. and Burnham, K. P. (2010) Distance software: design and analysis of distance sampling surveys for estimating population size. J. Appl. Ecol. 47: 5-14.

Turpie, J. K., Marais, C. and Blignaut, J. N. (2008) The working for water programme: Evolution of a payments for ecosystem services mechanism that addresses both poverty and ecosystem service delivery in South Africa. Ecol. Econ. 65: 788-798.

Wilson, A. M., Latimer, A. M., Silander, J. A., Jr., Gelfand, A. E. and de Klerk, H. (2010) A hierarchical Bayesian model of wildfire in a Mediterranean biodiversity hotspot: implications of weather variability and global circulation. Ecol. Modell. 221: 106-112.

Young, N., Carter, L. and Evangelista, P. (2011) A MaxEnt model v3. 3.3 e tutorial (ArcGIS v10). Colorado, USA: Natural Resource Ecology Laboratory at Colorado State University and the National Institute of Invasive Species Science.

\author{
ALAN T. K. LEE* \\ Climate Change Adaptation Division, South African National Biodiversity Institute, Private \\ Bag X7, Claremont 7735, South Africa.

\section{PHOEBE BARNARD} \\ Percy FitzPatrick Institute of African Ornithology, DST/NRF Centre of Excellence, University of \\ Cape Town, Private Bag $X_{3}$, Rondebosch 7701, South Africa. \\ *Author for correspondence; email:alan.tk.lee@googlemail.com
}

Received 22 May 2014; revision accepted 10 December 2014; Published online 2 February 2015 